Article

\title{
Linear One-Dimensional Coordination Polymers Constructed by Dirhodium Paddlewheel and Tetracyanido-Metallate Building Blocks
}

\author{
David Prior ${ }^{1}$, Miguel Cortijo ${ }^{1} \mathbb{D}$, Rodrigo González-Prieto ${ }^{1, *}$, Santiago Herrero ${ }^{1} \mathbb{D}$, \\ Reyes Jiménez-Aparicio ${ }^{1}$, Josefina Perles ${ }^{2, *} \mathbb{D}$ and José Luis Priego ${ }^{1, *}$ \\ 1 Departamento de Química Inorgánica, Facultad de Ciencias Químicas, Universidad Complutense de \\ Madrid, 28040 Madrid, Spain; david.prior@ucm.es (D.P.); miguelcortijomontes@ucm.es (M.C.); \\ sherrero@ucm.es (S.H.); reyesja@ucm.es (R.J.-A.) \\ 2 Laboratorio de Difracción de Rayos X de Monocristal, Servicio Interdepartamental de Investigación (SIdI), \\ Universidad Autónoma de Madrid, 28049 Madrid, Spain \\ * Correspondence: rodgonza@ucm.es (R.G.-P.); josefina.perles@uam.es (J.P.); bermejo@ucm.es (J.L.P.)
}

Received: 26 October 2019; Accepted: 21 November 2019; Published: 23 November 2019

check for updates

\begin{abstract}
In this article, we describe the preparation of anionic heteronuclear one-dimensional coordination polymers made by dirhodium paddlewheels and tetracyanido-metallatate building blocks. A series of complexes of $\left(\mathrm{PPh}_{4}\right)_{2 \mathrm{n}}\left[\left\{\mathrm{Rh}_{2}\left(\mu-\mathrm{O}_{2} \mathrm{CCH}_{3}\right)_{4}\right\}\left\{\mathrm{M}(\mathrm{CN})_{4}\right\}\right]_{\mathrm{n}}(\mathrm{M}=\mathrm{Ni}(\mathbf{1})$, $\mathrm{Pd}(2), \mathrm{Pt}(3))$ formulae were obtained by reaction of $\left[\mathrm{Rh}_{2}\left(\mu-\mathrm{O}_{2} \mathrm{CCH}_{3}\right)_{4}\right]$ with $\left(\mathrm{PPh}_{4}\right)_{2}\left[\mathrm{M}(\mathrm{CN})_{4}\right]$ in a 1:1 or 2:1 ratio. Crystals of 1-3 suitable for single crystal X-ray diffraction were grown by slow diffusion of a dichloromethane solution of the dirhodium complex into a chloroform solution of the corresponding tetracyanido-metallatate salt. Compounds $\mathbf{1}$ and $\mathbf{2}$ are isostructural and crystallize in the triclinic $P-1$ space group, while compound 3 crystallizes in the monoclinic $P 2_{1} / n$ space group. A detailed description of the structures is presented, including the analysis of the packing of anionic chains and $\mathrm{PPh}_{4}^{+}$cations.
\end{abstract}

Keywords: dirhodium compounds; tetracyanido-metallatate complexes; one-dimensional coordination polymers

\section{Introduction}

Dinuclear complexes with a paddlewheel structure show a rich chemistry and different electronic configurations as a consequence of the distribution of the energy levels and the number of electrons in the dimetallic unit [1,2]. Dirhodium complexes and, in particular, the tetracarboxylato derivatives, are among the most important and versatile paddlewheel compounds [1,2], and their reactivity has been explored in several fields such as catalysis [3-9] or bioinorganic chemistry [10-13]. The ground state electron configuration for most of these complexes is $\sigma^{2} \pi^{4} \delta^{2} \delta^{* 2} \pi^{* 4}$ for a diamagnetic $\mathrm{Rh}_{2}{ }^{4+}$ unit, which, therefore, displays a single metal-metal bond order [1,2].

Many dirhodium molecular complexes have been reported owing to the facility of the rhodium ions to coordinate monodentate donor ligands at the axial positions of the paddlewheel structure [1,2,14-17]. Moreover, dirhodium units have been used to form one-dimensional coordination compounds using bridging ligands between the dimetallic cores [18-21]. The use of other metal complexes as connectors between the paddlewheel units can lead to the formation of heterometallic one-dimensional coordination polymers, whose versatile chemical and physical properties, such as temperature dependent luminescence or modulation of their electronic structures, make those polymers promising materials [22-25]. An interesting approach to obtain this kind of 
heterometallic one-dimensional polymers is the use of platinum complexes to form $\left\{\left[\mathrm{Rh}_{2}\right]-\left[\mathrm{Pt}_{2}\right]-\left[\mathrm{Pt}_{2}\right]\right\}_{\mathrm{n}}$ chains, in which the different dimetallic units show direct Rh-Pt metal-metal bonds [26-29]. Paramagnetic $\left[\mathrm{Rh}_{2}\right]-[\mathrm{Pt}-\mathrm{Cu}-\mathrm{Pt}]$ chains can be synthesized, also inserting a copper complex $[30,31]$. In addition, several heterometallic one-dimensional polymers using dicyanidoaurate, $\left[\mathrm{Au}(\mathrm{CN})_{2}\right]^{-}[32]$, or dicyanidoargentate, $\left[\mathrm{Ag}(\mathrm{CN})_{2}\right]^{-}[33]$, as bridging axial ligands have been reported by our research group. The use of cyanide-bridged cyanidometallates to form heterometallic complexes has been widely reported in the literature, owing to the diversity in the topologies and dimensionalities found in those complexes and to the interesting magnetic or optical properties showed by some of them [34-40].

The use of charged cyanidometallates to bridge the neutral $\mathrm{Rh}(\mathrm{II})-\mathrm{Rh}(\mathrm{II})$ units requires the presence of counter-cations to compensate the negative charge, which can simply be alkali cations [32] or bulkier groups like tetraphenylphosphonium [33]. The interest of the latter lays in its higher arrangement diversity owing to the supramolecular structures that can be formed by phenyl-phenyl interactions through double, quadruple, or sextuple phenyl embraces [33,41-44].

In this work, we examine the reaction of $\left[\mathrm{Rh}_{2}\left(\mu-\mathrm{O}_{2} \mathrm{CCH}_{3}\right)_{4}\right]$ with $\left(\mathrm{PPh}_{4}\right)_{2}\left[\mathrm{M}(\mathrm{CN})_{4}\right](\mathrm{M}=\mathrm{Ni}, \mathrm{Pd}$, $\mathrm{Pt})$. The presence of four $\mathrm{CN}^{-}$groups in the $\left[\mathrm{M}(\mathrm{CN})_{4}\right]^{2-}$ ion gives a great coordination versatility that could lead to discrete molecular compounds, one-dimensional structures, or bi-dimensional structures. Thus, in this paper, we describe the synthesis, characterization, and structural description of the heterometallic one-dimensional complexes $\left(\mathrm{PPh}_{4}\right)_{2 \mathrm{n}}\left[\left\{\mathrm{Rh}_{2}\left(\mu-\mathrm{O}_{2} \mathrm{CCH}_{3}\right)_{4}\right\}\left\{\mathrm{M}(\mathrm{CN})_{4}\right\}\right]_{\mathrm{n}}(\mathrm{M}=\mathrm{Ni}(\mathbf{1}), \mathrm{Pd}(\mathbf{2})$, $\mathrm{Pt}(3))$, using $\left[\mathrm{M}(\mathrm{CN})_{4}\right]^{2-}$ groups as bridging ligands.

\section{Materials and Methods}

\subsection{Materials and Physical Measurements}

$\left(\mathrm{PPh}_{4}\right)_{2}\left[\mathrm{M}(\mathrm{CN})_{4}\right](\mathrm{M}=\mathrm{Ni}, \mathrm{Pd})$ salts were prepared by reaction of a $15 \mathrm{~mL}$ water solution of $0.100 \mathrm{~g}$ of the corresponding $\mathrm{K}_{2}\left[\mathrm{M}(\mathrm{CN})_{4}\right](\mathrm{M}=\mathrm{Ni}$, Pd) compound with a $15 \mathrm{~mL}$ water solution of two equivalents of $\mathrm{PPh}_{4} \mathrm{Br}$. The mixture was stirred for $30 \mathrm{~min}$ and the white solid obtained was filtered and washed with water and diethyl ether. Yield: $\left(\mathrm{PPh}_{4}\right)_{2}\left[\mathrm{Ni}(\mathrm{CN})_{4}\right], 0.200 \mathrm{~g}(57 \%)$. $\left(\mathrm{PPh}_{4}\right)_{2}\left[\mathrm{Pd}(\mathrm{CN})_{4}\right]$, $0.230 \mathrm{~g}(75 \%)$. $\left(\mathrm{PPh}_{4}\right)_{2}\left[\mathrm{Pt}(\mathrm{CN})_{4}\right]$ was prepared by the following procedure: a solution of $0.100 \mathrm{~g}$ of $\mathrm{K}_{2}\left[\mathrm{PtCl}_{4}\right](0.24 \mathrm{mmol})$ in $10 \mathrm{~mL}$ of water was mixed with a solution of $0.120 \mathrm{~g}$ of $\mathrm{NaCN}(2.45 \mathrm{mmol})$ in $10 \mathrm{~mL}$ of water. The mixture was stirred for $24 \mathrm{~h}$ and a solution of $0.200 \mathrm{~g}$ of $\mathrm{PPh}_{4} \mathrm{Br}(0.48 \mathrm{mmol})$ in $15 \mathrm{~mL}$ of water was added, immediately obtaining a white precipitate. The stirring was kept for $30 \mathrm{~min}$ and the solid was filtered and washed with water and diethyl ether. Yield: $0.170 \mathrm{~g}(72 \%)$. The rest of the reactants and solvents were obtained from commercial sources and used as received.

The elemental analysis measurements were carried out by the Elemental Analysis Service of the Universidad Complutense of Madrid. The FTIR spectra were collected with a Perkin-Elmer Spectrum 100 Spectrometer equipped with a universal ATR accessory in the $4000-650 \mathrm{~cm}^{-1}$ range. The mass spectra were collected by the Mass Spectrometry Service of the Universidad Complutense of Madrid using the electrospray ionization (ESI) technique and an ion trap-Bruker Esquire-LC spectrometer. Single crystal X-ray diffraction data were collected using an Oxford Diffraction Atlas diffractometer with Mo K $_{\alpha}(\lambda=0.71073 \AA)$ radiation at room temperature. CCDC 1954793-1954795 contain the crystallographic data. These data can be obtained free of charge from the Cambridge Crystallographic Data Centre via www.ccdc.cam.ac.uk/data_request/cif. A summary of some crystal and refinement data can be found in Table 1, and more information is collected in the Supplementary Material in Tables S1-S6. 
Table 1. Crystal and refinement data for 1-3.

\begin{tabular}{|c|c|c|c|}
\hline & $1(\mathrm{M}=\mathrm{Ni})$ & $2(\mathrm{M}=\mathrm{Pd})$ & $3(\mathbf{M}=\mathbf{P t})$ \\
\hline Formula & \multicolumn{3}{|c|}{$\left(\mathrm{PPh}_{4}\right)_{2 \mathrm{n}}\left[\left\{\mathrm{Rh}_{2}\left(\mu-\mathrm{O}_{2} \mathrm{CCH}_{3}\right)_{4}\right\}\left\{\mathrm{M}(\mathrm{CN})_{4}\right\}\right]_{\mathrm{n}}$} \\
\hline fw & 1283.51 & 1331.21 & 1419.90 \\
\hline Space group & $P-1$ & $P-1$ & $P 2_{1} / n$ \\
\hline$a / \AA$ & $12.669(1)$ & $12.636(1)$ & $13.0959(4)$ \\
\hline$b / \AA$ & $12.8404(8)$ & $13.095(2)$ & $11.7615(4)$ \\
\hline$c / \AA$ & $14.640(1)$ & $14.524(2)$ & $25.132(1)$ \\
\hline$\alpha /^{\circ}$ & $84.405(5)$ & $85.137(9)$ & 90 \\
\hline$\beta /^{\circ}$ & $67.765(7)$ & $68.479(9)$ & $101.613(4)$ \\
\hline$\gamma /{ }^{\circ}$ & $70.795(7)$ & $70.436(9)$ & 90 \\
\hline$V / \AA^{3}$ & $2080.7(3)$ & 2104.7(4) & $3791.8(2)$ \\
\hline Z & 1 & 1 & 2 \\
\hline$d \mathrm{calc} / g \cdot \mathrm{cm}^{-3}$ & 1.024 & 1.052 & 1.244 \\
\hline$\mu / \mathrm{mm}^{-1}$ & 0.694 & 0.676 & 2.356 \\
\hline$R$ indices $(\mathrm{I}>2 \sigma(\mathrm{I}))$ & $\begin{array}{c}R_{1}=0.0740 \\
w R_{2}=0.2276\end{array}$ & $\begin{array}{c}R_{1}=0.0662 \\
w R_{2}=0.1699\end{array}$ & $\begin{array}{c}R_{1}=0.0395 \\
w R_{2}=0.1046\end{array}$ \\
\hline GooF on $F^{2}$ & 1.017 & 1.005 & 1.008 \\
\hline
\end{tabular}

\subsection{Synthesis}

Synthesis of $\left(\mathrm{PPh}_{4}\right)_{2 n}\left[\left\{\mathrm{Rh}_{2}\left(\mu-\mathrm{O}_{2} \mathrm{CCH}_{3}\right)_{4}\right\}\left\{\mathrm{M}(\mathrm{CN})_{4}\right\}\right]_{\mathrm{n}}(\mathrm{M}=\mathrm{Ni}(\mathbf{1}), \operatorname{Pd}(\mathbf{2}), \operatorname{Pt}(\mathbf{3}))$

A solution of $0.11 \mathrm{mmol}\left(\mathrm{PPh}_{4}\right)_{2}\left[\mathrm{M}(\mathrm{CN})_{4}\right](\mathrm{M}=\mathrm{Ni}, \mathrm{Pd}, \mathrm{Pt})$ in $15 \mathrm{~mL}$ of $\mathrm{CH}_{2} \mathrm{Cl}_{2}$ was added to a solution of $0.050 \mathrm{~g}$ of $\left[\mathrm{Rh}_{2}\left(\mu-\mathrm{O}_{2} \mathrm{CCH}_{3}\right)_{4}\right](0.11 \mathrm{mmol})$ in $15 \mathrm{~mL}$ of $\mathrm{CH}_{2} \mathrm{Cl}_{2}$, immediately obtaining a pink precipitate. The mixture was stirred for $24 \mathrm{~h}$ and the solid was filtered and washed with $\mathrm{CH}_{2} \mathrm{Cl}_{2}$.

(1) Yield. $0.068 \mathrm{~g}(48 \%)$. Anal.Calcd. (\%) for $1 \cdot \mathrm{CH}_{2} \mathrm{Cl}_{2}: \mathrm{C}, 53.54 ; \mathrm{H}, 3.98 ; \mathrm{N}, 4.09$. Found (\%): $\mathrm{C}$, 53.26; H, 4.05; N, 4.20. FT-IR (cm $\left.{ }^{-1}\right)$ : 3061 w, 2992 w, 2137 w, 2120 w, 1597 s, 1484 w, 1436 s, 1408 s, 1342 w, 1315 w, 1108 s, $997 \mathrm{~m}, 760 \mathrm{~m}, 721$ vs, 690 vs. ESI ${ }^{-}, \mathrm{m} / \mathrm{z}=501\left[\left(\mathrm{PPh}_{4}\right) \mathrm{Ni}(\mathrm{CN})_{4}\right]^{-} ; 943\left[\mathrm{M}-\left(\mathrm{PPh}_{4}\right)\right]^{-}$; $1385\left[\mathrm{M}+\mathrm{Rh}_{2}\left(\mathrm{O}_{2} \mathrm{CCH}_{3}\right)_{4}-\left(\mathrm{PPh}_{4}\right)\right]^{-}$.

(2) Yield. $0.082 \mathrm{~g}(56 \%)$. Anal.Calcd. (\%) for $2 \cdot 2 \mathrm{CH}_{2} \mathrm{Cl}_{2}: \mathrm{C}, 49.61 ; \mathrm{H}, 3.76 ; \mathrm{N}, 3.73$. Found (\%): $\mathrm{C}$, 49.82; H, 3.82; N, 3.92. FT-IR ( $\left.\mathrm{cm}^{-1}\right)$ : 3065 w, 2992 w, 2150w d, 2130 w, 1595 s, 1484 w, 1436 s, 1408 s, $1345 \mathrm{w}, 1316 \mathrm{w}, 1108 \mathrm{~s}, 996 \mathrm{~m}, 758 \mathrm{~m}, 722$ vs, 685 vs. ESI ${ }^{-}, \mathrm{m} / \mathrm{z}=549\left[\left(\mathrm{PPh}_{4}\right) \operatorname{Pd}(\mathrm{CN})_{4}\right]^{-} ; 991\left[\mathrm{M}-\left(\mathrm{PPh}_{4}\right)\right]^{-}$; $1433\left[\mathrm{M}+\mathrm{Rh}_{2}\left(\mathrm{O}_{2} \mathrm{CCH}_{3}\right)_{4}-\left(\mathrm{PPh}_{4}\right)\right]^{-}$.

(3) Yield. 0.060 g (38\%). Anal.Calcd. (\%) for 3. $\mathrm{CH}_{2} \mathrm{Cl}_{2}: \mathrm{C}, 48.69 ; \mathrm{H}, 3.62 ; \mathrm{N}, 3.72$. Found (\%): $\mathrm{C}$, 49.06; H, 3.74; N, 3.87. FTIR ( $\left.\mathrm{cm}^{-1}\right)$ : 3063 w, 2927 w, $2167 \mathrm{w}, 2146 \mathrm{w}, 1584$ vs, 1484 w, 1434 s, 1407 vs, $1344 \mathrm{~m}, 1108 \mathrm{~s}, 997 \mathrm{~m}, 756 \mathrm{~m}, 722$ vs, 690 vs. ESI ${ }^{-}, \mathrm{m} / \mathrm{z}=638\left[\left(\mathrm{PPh}_{4}\right) \mathrm{Pt}(\mathrm{CN})_{4}\right]^{-} ; 1080\left[\mathrm{M}-\left(\mathrm{PPh}_{4}\right)\right]^{-} ; 1522$ $\left[\mathrm{M}+\mathrm{Rh}_{2}\left(\mathrm{O}_{2} \mathrm{CCH}_{3}\right)_{4}-\left(\mathrm{PPh}_{4}\right)\right]^{-}$.

Purple crystals of $1-3$ suitable for single crystal X-ray diffraction were obtained after one week by slow diffusion of a solution of $0.050 \mathrm{~g}$ of $\left[\mathrm{Rh}_{2}\left(\mu-\mathrm{O}_{2} \mathrm{CCH}_{3}\right)_{4}\right](0.11 \mathrm{mmol})$ in $25 \mathrm{~mL}$ of $\mathrm{CH}_{2} \mathrm{Cl}_{2}$ into a solution of $0.06 \mathrm{mmol}$ of the corresponding $\left(\mathrm{PPh}_{4}\right)_{2}\left[\mathrm{M}(\mathrm{CN})_{4}\right]$ compound in $20 \mathrm{~mL}$ of $\mathrm{CHCl}_{3}$.

\section{Results and Discussion}

\subsection{Synthesis, Spectroscopic Characterization, and Spectrometric Characterization}

The synthesis of compounds $1-3$ was initially attempted using a 2:1 ratio of $\left[\mathrm{Rh}_{2}\left(\mu-\mathrm{O}_{2} \mathrm{CCH}_{3}\right)_{4}\right]$ and the corresponding $\left(\mathrm{PPh}_{4}\right)_{2}\left[\mathrm{M}(\mathrm{CN})_{4}\right]$ compound in order to prepare $2 \mathrm{D}$ coordination polymers. However, these reactions led to 1D coordination polymers in all cases, as shown by the crystal structures obtained. The presence of bulky $\mathrm{PPh}_{4}{ }^{+}$cations in the structure probably hinders the coordination of $\left[\mathrm{M}(\mathrm{CN})_{4}\right]^{2-}$ to four $\left[\mathrm{Rh}_{2}\left(\mathrm{O}_{2} \mathrm{CCH}_{3}\right)_{4}\right]$ units, leading to $1 \mathrm{D}$ arrangements instead. The reactions were repeated using a 1:1 ratio, obtaining products whose elemental analyses and IR spectra indicate both similar composition and coordination modes to those found in the crystal structures. Unfortunately, 
the lack of crystallinity in the obtained products from the 1:1 reactions does not allow the structural comparison of the solid state arrangement with the crystals from the 2:1 reactions.

Compounds 1-3 can be obtained by stirring a mixture of the reactants at room temperature. However, following this procedure, the products are obtained as solids that cannot be recrystallized because of the low solubility of the polymeric species in common solvents. In order to obtain single crystals of the products that allowed the structural determination of the compounds, slow diffusion of a solution of $\left[\mathrm{Rh}_{2}\left(\mu-\mathrm{O}_{2} \mathrm{CCH}_{3}\right)_{4}\right]$ in $\mathrm{CH}_{2} \mathrm{Cl}_{2}$ into a solution of the corresponding $\left(\mathrm{PPh}_{4}\right)_{2}\left[\mathrm{M}(\mathrm{CN})_{4}\right]$ in $\mathrm{CHCl}_{3}$ was employed. $\left(\mathrm{PPh}_{4}\right)_{2}\left[\mathrm{M}(\mathrm{CN})_{4}\right]$ salts were used instead of the commercially available $\mathrm{K}_{2}\left[\mathrm{M}(\mathrm{CN})_{4}\right]$ salts in order to use organic solvents in the reactions.

The IR spectra of all the compounds display bands corresponding to the symmetric and asymmetric stretching modes of the carboxylate groups: $\mathrm{COO}_{\mathrm{as}}\left(1597-1584 \mathrm{~cm}^{-1}\right) ; \mathrm{COO}_{\mathrm{sym}}\left(1450-1400 \mathrm{~cm}^{-1}\right)$. The C-H stretching bands of the aliphatic and aromatic groups appear below and above $3000 \mathrm{~cm}^{-1}$, respectively. Moreover, two bands are observed between 2167 and $2120 \mathrm{~cm}^{-1}$ in all cases corresponding to the $\mathrm{CN}^{-}$groups. The lower energy band corresponds to terminal $\mathrm{CN}^{-}$ligands (not coordinated to $\mathrm{Rh}_{2}$ units), while the higher energy band corresponds to bridging $\mathrm{CN}^{-}$ligands, coordinated to $\mathrm{Rh}_{2}$ units.

The base peak of the ESI ${ }^{-}$mass spectra of 1-3 corresponds to $\left[\left(\mathrm{PPh}_{4}\right) \mathrm{M}(\mathrm{CN})_{4}\right]^{-}$. A peak close to the base peak that corresponds to $\left[\mathrm{M}-\left(\mathrm{PPh}_{4}\right)\right]^{-}$is also present in all the spectra, as well as a peak assigned to $\left[\mathrm{M}+\mathrm{Rh}_{2}\left(\mathrm{O}_{2} \mathrm{CCH}_{3}\right)_{4}-\left(\mathrm{PPh}_{4}\right)\right]^{-}$. This last peak indicates polymerization of the complexes, although it could also be caused by an association process during the measurements.

\subsection{Structural Description}

The crystal structures of 1-3 were determined by single crystal X-ray diffraction. Complexes $\mathbf{1}$ and 2 are isostructural and crystallize in the $P-1$ space group, while compound 3 crystallizes in the $P 2_{1} / n$ space group (Table 1 ). The three compounds comprise anionic $1 \mathrm{D}$ chains with the formula $\left[\left\{\mathrm{Rh}_{2}\left(\mu-\mathrm{O}_{2} \mathrm{CCH}_{3}\right)_{4}\right\}\left\{\mathrm{M}(\mathrm{CN})_{4}\right\}\right]_{\mathrm{n}}{ }^{2 \mathrm{n}-}$ and interstitial $\mathrm{PPh}_{4}{ }^{+}$cations to balance the negative charges.

The structure of the $1 \mathrm{D}$ anionic polymer is remarkably similar in the two structural types and consists of dirhodium paddlewheel units joined by $\left\{\mathrm{M}(\mathrm{CN})_{4}\right\}$ moieties. Figures S1-S3 show the asymmetric units of $\mathbf{1}, \mathbf{2}$, and 3, Figures S4 and S5 show their coordination environments, and Table 2 shows a selection of bond lengths and angles in 1-3; collected in more detail in Sections S4 and S5, Tables S7-S10. There are highly disordered solvent molecules in the crystals, which could not be satisfactorily modelled, and were removed with SQUEEZE software [45].

Table 2. Selected bond lengths $(\AA)$ and angles $\left(^{\circ}\right)$ in 1-3.

\begin{tabular}{cccc}
\hline & $\mathbf{1} \mathbf{( M = N i )}$ & $\mathbf{2}(\mathbf{M}=\mathbf{P d})$ & $\mathbf{3} \mathbf{M}=\mathbf{P t})$ \\
\hline Rh-Rh & $2.394(1)$ & $2.3968(9)$ & $2.4007(8)$ \\
Rh-N & $2.275(6)$ & $2.246(5)$ & $2.209(5)$ \\
& $2.019(5)$ & $2.020(4)$ & $2.026(4)$ \\
Rh-O & $2.024(5)$ & $2.031(4)$ & $2.029(4)$ \\
& $2.035(5)$ & $2.040(4)$ & $2.035(4)$ \\
M-C5 (bridge CN) & $2.041(5)$ & $2.052(4)$ & $2.042(4)$ \\
M-C6 (terminal CN) & $1.888(8)$ & $2.080(6)$ & $1.998(6)$ \\
C5-N1 (bridge CN) & $1.850(8)$ & $1.960(8)$ & $1.979(8)$ \\
C6-N2 (terminal CN) & $1.062(9)$ & $1.031(7)$ & $1.144(8)$ \\
Rh-Rh-N & $1.14(1)$ & $1.151(9)$ & $1.127(9)$ \\
Rh-N-C & $178.4(2)$ & $179.1(1)$ & $178.2(1)$ \\
C5-M-C6 & $178.0(8)$ & $172.5(5)$ & $175.8(5)$ \\
& $88.8(3)$ & $88.9(2)$ & $89.9(3)$ \\
\end{tabular}

Concerning the $\left\{\mathrm{Rh}_{2}\left(\mu-\mathrm{O}_{2} \mathrm{CCH}_{3}\right)_{4}\right\}$ paddlewheel dimers, the rhodium atoms are joined by a single metal-metal bond and bridged by four acetate ligands, with an inversion center 
located in the middle of the $\mathrm{Rh}-\mathrm{Rh}$ bond. Regarding the $\mathrm{Rh}$ coordination environment geometry, Rh-Rh bond (2.394(1)-2.4007(8) $\AA$ ) values are very similar in the three cases to those found in the literature for similar compounds: $\mathrm{K}_{\mathrm{n}}\left[\left\{\mathrm{Rh}_{2}\left(\mu-\mathrm{O}_{2} \mathrm{CCH}_{3}\right)_{4}\right\}\left\{\mathrm{Au}(\mathrm{CN})_{2}\right\}\right]_{\mathrm{n}}$ [32], $\left[\left\{\mathrm{Rh}_{2}\left(\mu-\mathrm{O}_{2} \mathrm{CCH}_{3}\right)_{4}\right\}\left\{\mathrm{PtCl}_{4}\right\}\right]_{\mathrm{n}},[46],\left(\mathrm{PPh}_{4}\right)_{\mathrm{n}}\left[\left\{\mathrm{Rh}_{2}\left(\mu-\mathrm{O}_{2} \mathrm{CR}\right)_{4}\right\}\left\{\mathrm{Ag}(\mathrm{CN})_{2}\right\}\right]_{\mathrm{n}}\left(\mathrm{R}=\mathrm{Me}, \mathrm{Ph}, \mathrm{CH}_{2} \mathrm{OEt}\right)$ [33], $\left[\mathrm{K}\left(18 \text {-crown-6) }\left(\mathrm{H}_{2} \mathrm{O}\right)\right]_{2 \mathrm{n}}\left[\mathrm{K}\left(18 \text {-crown-6) }\left(\mathrm{H}_{2} \mathrm{O}\right)_{2}\right]_{\mathrm{n}}\left[\left\{\mathrm{Rh}_{2}\left(\mu-\mathrm{O}_{2} \mathrm{CPh}\right)_{4}\right\}\left\{\mathrm{Fe}(\mathrm{CN})_{6}\right\}\right]_{n} \cdot 8 \mathrm{nH}_{2} \mathrm{O} \quad\right.\right.$ [47], and $\mathrm{K}_{3 \mathrm{n}}\left[\left\{\mathrm{Rh}_{2}\left(\mu-\mathrm{O}_{2} \mathrm{CCH}_{3}\right)_{4}\right\}_{2}\left\{\mathrm{Co}(\mathrm{CN})_{6}\right\}\right]_{\mathrm{n}}[48]$. The Rh-O distances in 1-3 (2.019(5)-2.052(4) $\left.\mathrm{A}\right)$ are also very similar to the values found in these analogous compounds.

In the tetracyano-metallate units, the metal atom is located at an inversion center, and these fragments bridge two dimetallic units by two $\mathrm{CN}^{-}$groups in trans disposition coordinated to the axial positions of the rhodium atoms. The Rh-N distances range from 2.209(5) to 2.275(6) $\AA$, close to those of $\mathrm{K}_{\mathrm{n}}\left[\left\{\mathrm{Rh}_{2}\left(\mu-\mathrm{O}_{2} \mathrm{CCH}_{3}\right)_{4}\right\}\left\{\mathrm{Au}(\mathrm{CN})_{2}\right\}\right]_{\mathrm{n}}$ [32], $\left(\mathrm{PPh}_{4}\right)_{\mathrm{n}}\left[\left\{\mathrm{Rh}_{2}\left(\mu-\mathrm{O}_{2} \mathrm{CR}\right)_{4}\right\}\left\{\mathrm{Ag}(\mathrm{CN})_{2}\right\}\right]_{\mathrm{n}}[33]$, $\left[\mathrm{K}\left(18 \text {-crown-6) }\left(\mathrm{H}_{2} \mathrm{O}\right)\right]_{2 \mathrm{n}}\left[\mathrm{K}\left(18-\text { crown-6) }\left(\mathrm{H}_{2} \mathrm{O}\right)_{2}\right]_{\mathrm{n}}\left[\left\{\mathrm{Rh}_{2}\left(\mu-\mathrm{O}_{2} \mathrm{CPh}\right)_{4}\right\}\left\{\mathrm{Fe}(\mathrm{CN})_{6}\right\}\right]_{n} \cdot 8 \mathrm{nH}_{2} \mathrm{O} \quad\right.\right.$ [47], and $\mathrm{K}_{3 \mathrm{n}}\left[\left\{\mathrm{Rh}_{2}\left(\mu-\mathrm{O}_{2} \mathrm{CCH}_{3}\right)_{4}\right\}_{2}\left\{\mathrm{Co}(\mathrm{CN})_{6}\right\}\right]_{\mathrm{n}}[48]$.

The smaller size of Ni compared with Pd logically affects the M-C distance in the structures of $\mathbf{1}$ and 2. However, this effect is not observed when the structures of $\mathbf{2}(\mathrm{M}=\mathrm{Pd})$ and $\mathbf{3}(\mathrm{M}=\mathrm{Pt})$ are compared. The $\mathrm{C} 5-\mathrm{N} 1$ distance in the bridge $\mathrm{CN}^{-}$is slightly different depending on the $\mathrm{M}$ atom (1.062(9) $\AA$ for 1, 1.031(7) $\AA$ for 2, and 1.144(8) $\AA$ for 3). However, the C6-N2 distance in the terminal $\mathrm{CN}^{-}$ligands is very similar in the three compounds (1.14(1) $\AA$ for 1, 1.151(9) $\AA$ for 2, and 1.127(9) $\AA$ for 3 ). These C6-N2 distances are very similar to the values found in other complexes with terminal $\mathrm{CN}^{-}$ligands, such as $\left[\left\{\mathrm{Tm}(\mathrm{DMF})_{5}\left(\mathrm{H}_{2} \mathrm{O}\right)\right\}\left\{\mathrm{Ni}(\mathrm{CN})_{4}\right\}\right]_{2 \mathrm{n}}\left[\mathrm{Ni}(\mathrm{CN})_{4}\right]_{\mathrm{n}}(1.14-1.15 \AA)[49]$ and $[\mathrm{Hg}(\mathrm{CN})]_{\mathrm{n}}\left(\mathrm{NO}_{3}\right)_{\mathrm{n}}(1.12 \AA$ and $1.11 \AA ̊$ ) [50].

The structure of the chains of $\mathbf{1 - 3}$ is almost linear (Figure 1), in contrast to the

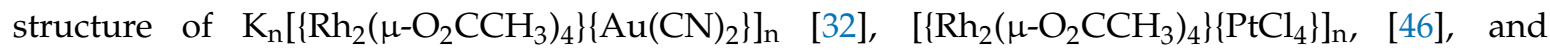
$\left(\mathrm{PPh}_{4}\right)_{n}\left[\left\{\mathrm{Rh}_{2}\left(\mu-\mathrm{O}_{2} \mathrm{CR}\right)_{4}\right\}\left\{\mathrm{Ag}(\mathrm{CN})_{2}\right\}\right]_{\mathrm{n}}\left(\mathrm{R}=\mathrm{Me}, \mathrm{Ph}, \mathrm{CH}_{2} \mathrm{OEt}\right)$ [33], which are formed by zigzag chains. The Rh-Rh-N angles in 1-3 $(\mathrm{M}=\mathrm{Ni}, \mathbf{1} ; \mathrm{Pd}, \mathbf{2} ; \mathrm{Pt}, 3)$ are $178.4(2)^{\circ}, 179.2(2)^{\circ}$, and $178.2(1)^{\circ}$, respectively, while $\mathrm{Rh}-\mathrm{N}-\mathrm{C}$ angles are $178.0(8)^{\circ}$ for $1,172.5(5)^{\circ}$ for 2 , and $175.8(5)^{\circ}$ for 3 . The $\mathrm{M} \cdots \mathrm{M}$ distance of the metals in $\left[\mathrm{M}(\mathrm{CN})_{4}\right]^{2-}$ groups is $12.840 \AA$ for $\mathbf{1}, 13.095 \AA$ for 2 , and $13.096 \AA$ for 3 . This distance is logically much longer than that found for similar chains with a zigzag disposition, for example, $\mathrm{K}_{\mathrm{n}}\left[\left\{\mathrm{Rh}_{2}\left(\mu-\mathrm{O}_{2} \mathrm{CCH}_{3}\right)_{4}\right\}\left\{\mathrm{Au}(\mathrm{CN})_{2}\right\}\right]_{\mathrm{n}}(\mathrm{Au}-\mathrm{Au}$ distance $=8.365 \AA)[32]$.
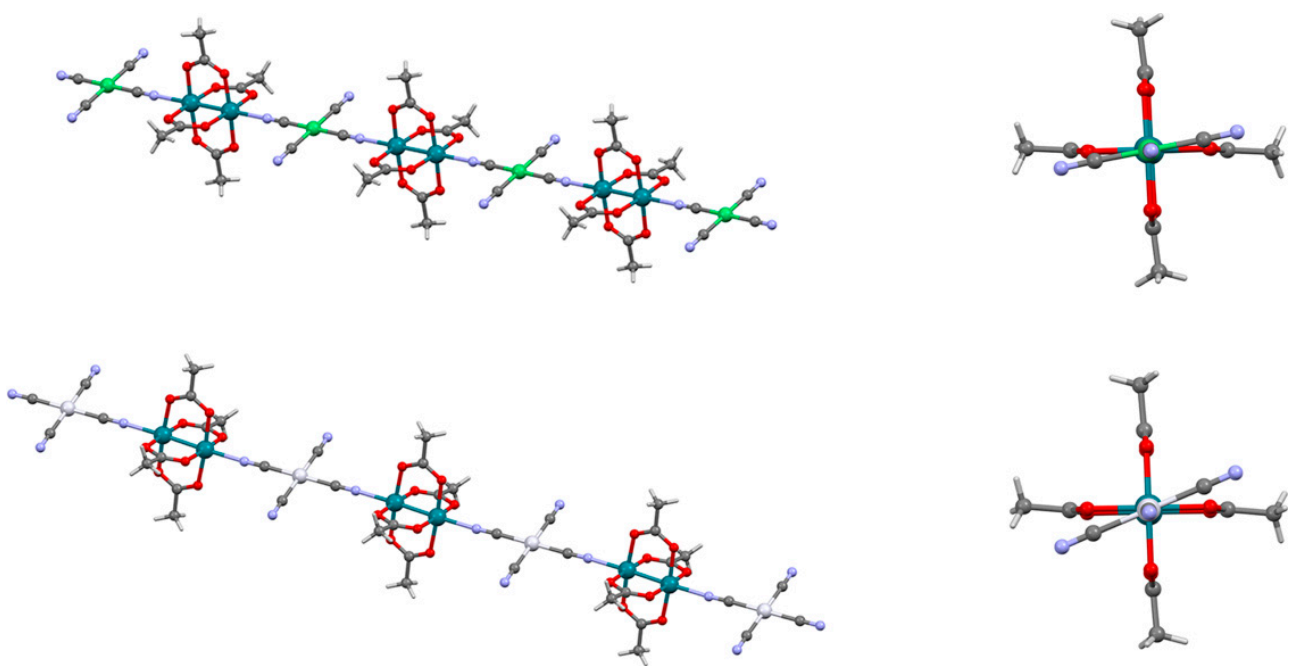

Figure 1. View of the $\left[\left\{\mathrm{Rh}_{2}\left(\mu-\mathrm{O}_{2} \mathrm{CCH}_{3}\right)_{4}\right\}\left\{\mathrm{M}(\mathrm{CN})_{4}\right\}\right]^{2 \mathrm{n}-}$ chains: left, chain in $\mathbf{1}$ (up) and $\mathbf{3}$ (down); right, view along the chain axis, $b$ in $\mathbf{1}$ (up) and $a$ in $\mathbf{3}$ (down).

An important structural difference is observed in the angle between the $\left\{\mathrm{M}(\mathrm{CN})_{4}\right\}$ plane and one of the planes in the paddlewheel molecule: in compounds $\mathbf{1}$ and $\mathbf{2}$, the two are almost parallel $\left(10.30^{\circ}\right.$ 
in $\mathbf{1}$ and $6.23^{\circ}$ in 2$)$, while in compound 3 , the value is considerably higher $\left(22.64^{\circ}\right)$, as can be seen in Figure 1 (right).

However, the main difference between the two structural types lies in the arrangement of the anionic chains and the molecular cations in the crystal (see Figure 2). The packing is achieved in the three compounds by $\mathrm{C}-\mathrm{H} \cdots \pi$ interactions between hydrogen atoms from the acetate ligands and some of the rings in the $\mathrm{PPh}_{4}{ }^{+}$cations (Figures S6 and S7, and Tables S11 and S12). In the structure of compounds $\mathbf{1}$ and $\mathbf{2}$, only four hydrogen atoms in each paddlewheel unit participate in these interactions, while in compound 3, six C-H $\cdots \pi$ interactions are established, resulting in a denser packing.
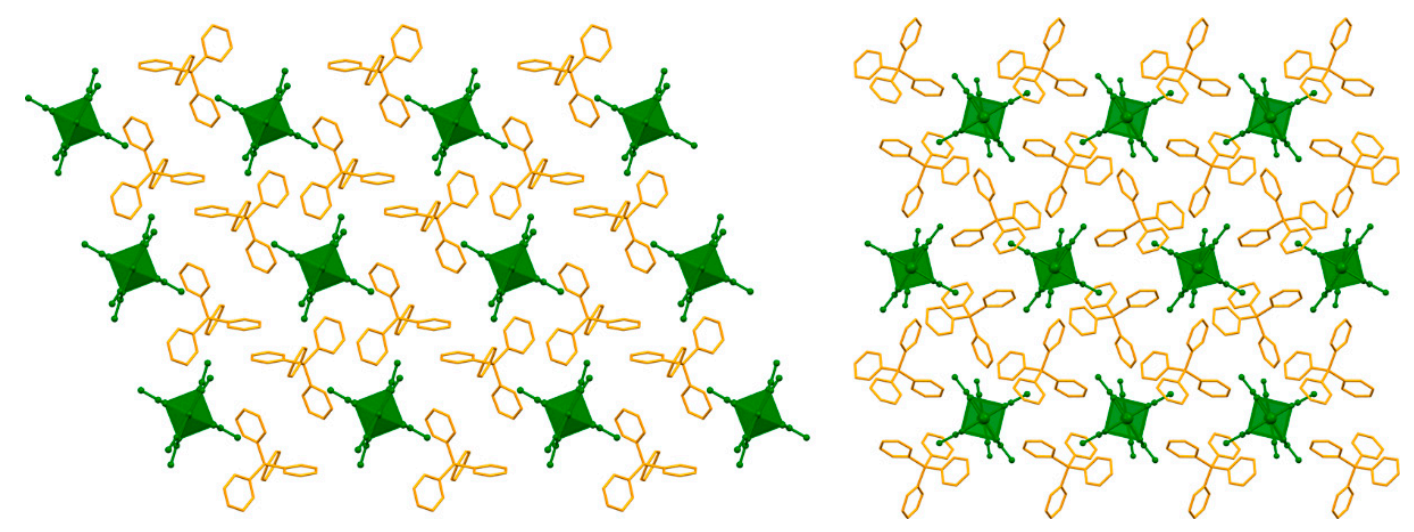

Figure 2. View along the chain axis of the packing of the anionic $1 \mathrm{D}$ polymers and the $\mathrm{PPh}_{4}{ }^{+}$counterions in the structures of $\mathbf{1}$ and $\mathbf{2}$ (left) and $\mathbf{3}$ (right).

\section{Conclusions}

The room temperature reaction of $\left[\mathrm{Rh}_{2}\left(\mu-\mathrm{O}_{2} \mathrm{CCH}_{3}\right)_{4}\right]$ with $\left(\mathrm{PPh}_{4}\right)_{2}\left[\mathrm{M}(\mathrm{CN})_{4}\right](\mathrm{M}=\mathrm{Ni}, \mathrm{Pd}, \mathrm{Pt})$ leads to the formation of the one-dimensional complexes $\left(\mathrm{PPh}_{4}\right)_{2 n}\left[\left\{\mathrm{Rh}_{2}\left(\mu-\mathrm{O}_{2} \mathrm{CCH}_{3}\right)_{4}\right\}\left\{\mathrm{M}(\mathrm{CN})_{4}\right\}\right]_{n}$. The formation of 2D coordination polymers was not observed, regardless of the reagent ratio used. Probably, the presence of bulky $\mathrm{PPh}_{4}{ }^{+}$groups hinders the formation of two-dimensional networks. The crystal structure of these polymers consists of almost linear chains formed by $\left\{\mathrm{Rh}_{2}\left(\mu-\mathrm{O}_{2} \mathrm{CCH}_{3}\right)_{4}\right\}$ paddlewheel units axially bridged by two trans cyanide groups of the tetracyano-metallate moieties. The phenyl rings of the $\mathrm{PPh}_{4}{ }^{+}$cations are involved in $\mathrm{C}-\mathrm{H} \cdots \pi$ interactions with the hydrogen atoms from the acetate ligands, so the higher the number of involved hydrogen atoms, the denser the resulting packing.

Supplementary Materials: The following are available online at http://www.mdpi.com/2073-4352/9/12/614/s1, Figure S1: Asymmetric unit of compound 1. Table S1: Sample and crystal data for 1. Table S2: Data collection and structure refinement for 1. Figure S2: Asymmetric unit of compound 2. Table S3: Sample and crystal data for 2. Table S4: Data collection and structure refinement for 2. Figure S3: Asymmetric unit of compound 3. Table S5: Sample and crystal data for 3. Table S6: Data collection and structure refinement for 3. Figure S4. Coordination environments of metal atoms in $\mathbf{1}$ and 2. Table S7. Coordination environment distances $(\AA)$ in $\mathbf{1}$ and $\mathbf{2}$. Figure S5. Coordination environments of metal atoms in 3. Table S8. Coordination environment distances (Å) in 3 . Table S9. Coordination environment angles $\left({ }^{\circ}\right)$ in $\mathbf{1}$ and 2. Table S10. Coordination environment angles $\left({ }^{\circ}\right)$ in 3 . Figure S6. $\mathrm{C}-\mathrm{H} \cdots \pi$ interactions in $\mathbf{1}$ and $\mathbf{2}$. Table S11. Supramolecular interactions in $\mathbf{1}$ and 2. Figure S7. C $-\mathrm{H} \cdots \pi$ interactions in 3. Table S12. Supramolecular interactions in 3.

Author Contributions: R.J.-A. and J.L.P. conceived and designed the experiments; R.G.-P. supervised the experiments; D.P. performed the experiments; J.L.P., M.C., and S.H. analyzed the data; J.P. solved and analyzed the crystal structures; M.C., R.G.-P., and J.P. wrote and prepared the original draft.; R.J.-A., S.H., and J.P. reviewed the manuscript.

Funding: This research was funded by the Spanish Ministerio de Economía y Competitividad (project CTQ2015-63858-P, MINECO/FEDER) and Comunidad de Madrid (project B2017/BMD-3770-CM).

Conflicts of Interest: The authors declare no conflict of interest. The funders had no role in the design of the study; in the collection, analyses, or interpretation of data; in the writing of the manuscript, or in the decision to publish the results. 


\section{References}

1. Cotton, F.A.; Murillo, C.A.; Walton, R.A. Multiple Bonds between Metal Atoms, 3rd ed.; Springer: New York, NY, USA, 2005.

2. Liddle, S.T. (Ed.) Molecular Metal-Metal Bonds: Compounds, Synthesis, Properties; Wiley-VCH: Weinheim, Germany, 2015.

3. Hui, B.C.Y.; Teo, W.K.; Rempel, G.L. Activation of hydrogen by bridged transition metal carboxylates. Rhodium(II) acetate catalyzed hydrogenation of olefins. Inorg. Chem. 1973, 12, 757-762. [CrossRef]

4. Hubert, A.J.; Noels, A.F.; Anciaux, A.J.; Teyssié, P. Rhodium(II) carboxylates: Novel highly efficient catalysts for the cyclopropanation of alkenes with alkyl diazoacetates. Synthesis 1976, 9, 600-602. [CrossRef]

5. Davies, H.M.L.; Liao, K. Dirhodium tetracarboxylates as catalysts for selective intermolecular $\mathrm{C}-\mathrm{H}$ functionalization. Nat. Rev. Chem. 2019, 3, 347-360. [CrossRef]

6. Huang, M.-Y.; Yang, J.-M.; Zhao, Y.-T.; Zhu, S.-F. Rhodium-Catalyzed Si-H Bond Insertion Reactions Using Functionalized Alkynes as Carbene Precursors. ACS Catal. 2019, 9, 5353-5357. [CrossRef]

7. Adly, F.G.; Gardiner, M.G.; Ghanem, A. Design and Synthesis of Novel Chiral Dirhodium(II) Carboxylate Complexes for Asymmetric Cyclopropanation Reactions. Chem. Eur. J. 2016, 22, 3447-3461. [CrossRef] [PubMed]

8. Warzecha, E.; Berto, T.C.; Berry, J.F. Axial Ligand Coordination to the C-H Amination Catalyst $\mathrm{Rh}_{2}(\mathrm{esp})_{2}$ : A Structural and Spectroscopic Study. Inorg. Chem. 2015, 54, 8817-8824. [CrossRef] [PubMed]

9. Mukhacheva, A.A.; Volchek, V.V.; Abramov, P.A.; Sokolov, M.N. Blocking $\{\mathrm{RhCl}\}^{2+}$ disorder in the crystal structure of a $\left[\mathrm{SiW}_{11} \mathrm{O}_{39}\{\mathrm{RhCl}\}\right]^{6-}$ salt: Direct localization of the heterometal in a monosubstituted Keggin anion. Inorg. Chem. Commun. 2018, 89, 10-12. [CrossRef]

10. Enriquez Garcia, A.; Lai, B.; Gopinathan, S.G.; Harris, H.H.; Shemanko, C.S.; Jalilehvand, F. Nuclear localization of dirhodium(II) complexes in breast cancer cells by X-ray fluorescence microscopy. Chem. Commun. 2019, 55, 8223-8226. [CrossRef]

11. Lewis, J.C. Beyond the Second Coordination Sphere: Engineering Dirhodium Artificial Metalloenzymes To Enable Protein Control of Transition Metal Catalysis. Acc. Chem. Res. 2019, 52, 576-584. [CrossRef]

12. Masternak, J.; Gilewska, A.; Kazimierczuk, K.; Khavryuchenko, O.V.; Wietrzyk, J.; Trynda, J.; Barszcz, B. Synthesis, physicochemical and theoretical studies on new rhodium and ruthenium dimers. Relationship between structure and cytotoxic activity. Polyhedron 2018, 154, 263-274. [CrossRef]

13. Knoll, J.D.; Turro, C. Control and utilization of ruthenium and rhodium metal complex excited states for photoactivated cancer therapy. Coord. Chem. Rev. 2015, 282-283, 110-126. [CrossRef] [PubMed]

14. Gonzalez-Belman, O.F.; Varela, Y.; Flores-Álamo, M.; Wrobel, K.; Gutierrez-Granados, S.; Peralta-Hernández, J.M.; Jiménez-Halla, J.O.C.; Serrano, O. Microwave-Assisted Synthesis and Characterization of $\left[\mathrm{Rh}_{2}(\mathrm{OAc})_{4}(\mathrm{~L})_{2}\right]$ Paddlewheel Complexes: A Joint Experimental and Computational Study. Int. J. Inorg. Chem. 2017, 2017, 5435436. [CrossRef]

15. Ye, Q.-S.; Li, X.-N.; Jin, Y.; Yu, J.; Chang, Q.-W.; Jiang, J.; Yan, C.-X.; Li, J.; Liu, W.-P. Synthesis, crystal structures and catalytic activity of tetrakis(acetato)dirhodium(II) complexes with axial picoline ligands. Inorg. Chim. Acta 2015, 434, 113-120. [CrossRef]

16. Cmoch, P.; Głaszczka, R.; Jaźwiński, J.; Kamieński, B.; Senkara, E. Adducts of nitrogenous ligands with rhodium(II) tetracarboxylates and tetraformamidinate: NMR spectroscopy and density functional theory calculations. Magn. Reson. Chem. 2014, 52, 61-68. [CrossRef] [PubMed]

17. Milaeva, E.R.; Meleshonkova, N.N.; Shpakovsky, D.B.; Uspensky, K.V.; Dolganov, A.V.; Magdesieva, T.V.; Fionov, A.V.; Sidorov, A.A.; Aleksandrov, G.-G.; Eremenko, I.L. Synthesis and redox properties of dinuclear rhodium(II) carboxylates with 2,6-di-tert-butylphenol moieties. Inorg. Chim. Acta 2010, 363, 1455-1461. [CrossRef]

18. Kataoka, Y.; Yano, N.; Shimodaira, T.; Yan, Y.-N.; Yamasaki, M.; Tanaka, H.; Omata, K.; Kawamoto, T.; Handa, M. Paddlewheel-Type Dirhodium Tetrapivalate Based Coordination Polymer: Synthesis, Characterization, and Self-Assembly and Disassembly Transformation Properties. Eur. J. Inorg. Chem. 2016, 2810-2815. [CrossRef]

19. Fritsch, N.; Wick, C.R.; Waidmann, T.; Dral, P.O.; Tucher, J.; Heinemann, F.W.; Shubina, T.E.; Clark, T.; Burzlaff, N. Multiply Bonded Metal(II) Acetate (Rhodium, Ruthenium, and Molybdenum) Complexes with the trans-1,2-Bis(N-methylimidazol-2-yl)ethylene Ligand. Inorg. Chem. 2014, 53, 12305-12314. [CrossRef] 
20. Dikarev, E.V.; Shpanchenko, R.V.; Andreini, K.W.; Block, E.; Jin, J.; Petrukhina, M.A. Powder Diffraction Study of a Coordination Polymer Comprised of Rigid Building Blocks: $\left[\mathrm{Rh}_{2}\left(\mathrm{O}_{2} \mathrm{CCH}_{3}\right)_{4} \cdot \mu^{2}-\mathrm{Se}_{2} \mathrm{C}_{5} \mathrm{H}_{8}-S e, S e^{\prime}\right]_{\infty}$. Inorg. Chem. 2004, 43, 5558-5563. [CrossRef]

21. Kim, Y.; Kim, S.-J.; Lough, A.J. New dirhodium(II,II) carboxylates with 2,6-bis(N'-1,2,4-triazolyl)pyridinato ligand (btp). Polyhedron 2001, 20, 3073-3078. [CrossRef]

22. Heyduk, A.F.; Krodel, D.J.; Meyer, E.E.; Nocera, D.G. A Luminescent Heterometallic Dirhodium-Silver Chain. Inorg. Chem. 2002, 41, 634-636. [CrossRef]

23. Uemura, K. One-dimensional complexes extended by unbridged metal-metal bonds based on a HOMO-LUMO interaction at the $\mathrm{d}_{\mathrm{z}}{ }^{2}$ orbital between platinum and heterometal atoms. Dalton Trans. 2017, 46, 5474-5492. [CrossRef] [PubMed]

24. Sokolov, M.N.; Adonin, S.A.; Peresypkina, E.V.; Abramov, P.A.; Smolentsev, A.I.; Potemkin, D.I.; Snytnikov, P.V.; Fedin, V.P. Reactions of rhodium (II) acetate with non-lacunary Keggin and Dawson polyoxoanions and related catalytic studies. Inorg. Chim. Acta 2013, 394, 656-662. [CrossRef]

25. Adly, F.G.; Bollard, H.; Gardiner, M.G.; Ghanem, A. Chiral Dirhodium(II) Carboxylates: New Insights into the Effect of Ligand Stereo-Purity on Catalyst Structure and Enantioselectivity. Catalysts 2018, 8, 268. [CrossRef]

26. Uemura, K.; Ebihara, M. One-Dimensionally Extended Paddlewheel Dirhodium Complexes from Metal-Metal Bonds with Diplatinum Complexes. Inorg. Chem. 2011, 50, 7919-7921. [CrossRef] [PubMed]

27. Uemura, K.; Kanbara, T.; Ebihara, M. Two Types of Heterometallic One-Dimensional Alignment Composed of Acetamidate-Bridged Dirhodium and Pivalamidate-Bridged Diplatinum Complexes. Inorg. Chem. 2014, 53, 4621-4628. [CrossRef] [PubMed]

28. Uemura, K.; Yamada, T.; Kanbara, T.; Ebihara, M. Acetamidate-bridged paddlewheel dirhodium complex sandwiched by mononuclear platinum complexes with axial metal-metal bonds affording neutral heterometallic one-dimensional alignments. Inorg. Chim. Acta 2015, 424, 194-201. [CrossRef]

29. Yamada, T.; Ebihara, M.; Uemura, K. Heterometallic one-dimensional chain with tetradeca metal repetition constructed by amidate bridged dirhodium and pivalate bridged diplatinum complexes influenced by hydrogen bonding. Dalton Trans. 2016, 45, 12322-12328. [CrossRef]

30. Uemura, K.; Ebihara, M. Paramagnetic One-Dimensional Chains Comprised of Trinuclear Pt-Cu-Pt and Paddlewheel Dirhodium Complexes with Metal-Metal Bonds. Inorg. Chem. 2013, 52, 5535-5550. [CrossRef]

31. Uemura, K. Magnetic behavior in heterometallic one-dimensional chains or octanuclear complex regularly aligned with metal-metal bonds as -Rh-Rh-Pt-Cu-Pt. J. Mol. Struct. 2018, 1162, 31-36. [CrossRef]

32. Amo-Ochoa, P.; Delgado, S.; Gallego, A.; Gómez-García, C.J.; Jiménez-Aparicio, R.; Martínez, G.; Perles, J.; Torres, M.R. Structure and Properties of One-Dimensional Heterobimetallic Polymers Containing Dicyanoaurate and Dirhodium(II) Fragments. Inorg. Chem. 2012, 51, 5844-5849. [CrossRef]

33. Cruz, P.; Fernandez-Bartolome, E.; Cortijo, M.; Delgado-Martínez, P.; González-Prieto, R.; Priego, J.L.; Torres, M.R.; Jiménez-Aparicio, R. Synthesis and Structural Characterization of a Series of One-Dimensional Heteronuclear Dirhodium-Silver Coordination Polymers. Polymers 2019, 11, 111. [CrossRef]

34. Alexandrov, E.V.; Virovets, A.V.; Blatov, V.A.; Peresypkina, E.V. Topological Motifs in Cyanometallates: From Building Units to Three-Periodic Frameworks. Chem. Rev. 2015, 115, 12286-12319. [CrossRef] [PubMed]

35. Haque, F.; del Barco, E.; Fishman, R.S.; Miller, J.S. Low temperature hysteretic behavior of the interpenetrating 3-D network structured $\left[\mathrm{Ru}_{2}\left(\mathrm{O}_{2} \mathrm{CMe}\right)_{4}\right]_{3}\left[\mathrm{Fe}(\mathrm{CN})_{6}\right]$ magnet. Polyhedron 2013, 64, 73-76. [CrossRef]

36. Kennon, B.S.; Stone, K.H.; Stephens, P.W.; Miller, J.S. Interpenetrating diruthenium tetraformate monocation, $\left[\mathrm{Ru}^{\mathrm{II} / \mathrm{III}}{ }_{2}\left(\mathrm{O}_{2} \mathrm{CH}\right)_{4}\right]^{+}$, based 3-D molecule-based magnets. CrystEngComm 2009, 11, 2185-2191. [CrossRef]

37. Qin, Y.-L.; Yang, B.-W.; Wang, G.-F.; Sun, H. A cyanide-bridged heterometallic coordination polymer constructed from square-planar $\left[\mathrm{Ni}(\mathrm{CN})_{4}\right]^{2-}$ : Synthesis, crystal structure, thermal decomposition, electron paramagnetic resonance (EPR) spectrum and magnetic properties. Acta Cryst. 2016, C72, 555-560. [CrossRef] [PubMed]

38. Gör, K.; Tursun, M.; Keşan, G.; Kürkçüoğlu, G.S.; Rhyman, L.; Parlak, C.; Ramasami, P.; Yeşilel, O.Z.; Büyükgüngör, O. Novel Cyanide-Bridged Heterometallic Two-Dimensional Complex of 3-Methylpyridazine: Synthesis, Crystallographical, Vibrational, Thermal and DFT Studies. J. Inorg. Organomet. Polym. 2015, 25, 1205-1217. [CrossRef]

39. Manna, S.C.; Ribas, J.; Zangrando, E.; Chaudhuri, N.R. Hetero-metallic frameworks of $\left[\mathrm{Pd}(\mathrm{CN})_{4}\right]^{2-}$ and $\mathrm{Cu}(\mathrm{II})$ with triamines: A rare example of a tetracyanometallate bridged 2D coordination polymer. Polyhedron 2007, 26, 3189-3198. [CrossRef] 
40. Marinescu, G.; Madalan, A.M.; Andruh, M. New heterometallic coordination polymers based on zinc(II) complexes with Schiff-base ligands and dicyanometallates: Synthesis, crystal structures, and luminescent properties. J. Coord. Chem. 2015, 68, 479-490. [CrossRef]

41. Dance, I.; Scudder, M. Supramolecular Motifs: Concerted Multiple Phenyl Embraces between $\mathrm{Ph}_{4} \mathrm{P}^{+}$Cations Are Attractive and Ubiquitous. Chem. Eur. J. 1996, 2, 481-486. [CrossRef]

42. Dance, I.; Scudder, M. Concerted supramolecular motifs: Linear columns and zigzag chains of multiple phenyl embraces involving $\mathrm{Ph}_{4} \mathrm{P}^{+}$cations in crystals. J. Chem. Soc. Dalton Trans. 1996, 3755-3769. [CrossRef]

43. Ali, B.; Dance, I.; Scudder, M.; Craig, D. Dimorphs of $\left(\mathrm{Ph}_{4} \mathrm{P}\right)_{2}\left[\mathrm{Cd}_{2}(\mathrm{SPh})_{6}\right]$ : Crystal Packing Analyses and the Interplay of Intermolecular and Intramolecular Energies. Cryst. Growth Des. 2002, 2, 601-607. [CrossRef]

44. Zaręba, J.K.; Białek, M.J.; Janczak, J.; Zoń, J.; Dobosz, A. Extending the Family of Tetrahedral Tectons: Phenyl Embraces in Supramolecular Polymers of Tetraphenylmethane-based Tetraphosphonic Acid Templated by Organic Bases. Cryst. Growth Des. 2014, 14, 6143-6153. [CrossRef]

45. Spek, A.L. PLATON SQUEEZE: A tool for the calculation of the disordered solvent contribution to the calculated structure factors. Acta Cryst. 2015, C71, 9-18.

46. Yang, Z.; Ebihara, M.; Kawamura, T. One-dimensional chain structures constructed from tetra(acetamidato)dirhodium(II,III) complexes and square planar platinum and palladium complexes. Inorg. Chim. Acta 2006, 359, 2465-2471. [CrossRef]

47. Kim, Y.; Kim, S.J.; Nam, W. A ferric-cyanide-bridged one-dimensional dirhodium complex with (18-crown-6) potassium cations. Acta Cryst. 2001, C57, 266-268. [CrossRef] [PubMed]

48. Lu, J.; Harrison, W.T.A.; Jacobson, A.J. Synthesis and crystal structure of the two-dimensional polymer $\mathrm{K}_{3} \mathrm{Co}(\mathrm{CN})_{6} \cdot 2 \mathrm{Rh}_{2}\left(\mathrm{O}_{2} \mathrm{CMe}\right)_{4}$. Chem. Commun. 1996, 399-400. [CrossRef]

49. Park, D.; Song, M.; Ha, S.; Kang, A.-S.; Moon, S.-B.; Ryu, C.-H.; Chung, J.-H. A Novel Cyanide-Bridged Thulium-Nickel Heterobimetallic Polymeric Complex $\left\{\left(\mathrm{H}_{2} \mathrm{O}\right)_{2}(\mathrm{DMF})_{10} \mathrm{Tm}_{2}\left[\mathrm{Ni}(\mathrm{CN})_{4}\right]_{2}\right\}\left[\mathrm{Ni}(\mathrm{CN})_{4}\right]$ including O-H ... N Hydrogen Bond. Bull. Korean Chem. Soc. 2012, 33, 4197-4200. [CrossRef]

50. Korčok, J.L.; Leznoff, D.B. Thermal expansion of mercury(II) cyanide and $\mathrm{HgCN}\left(\mathrm{NO}_{3}\right)$. Polyhedron 2013, 52, 72-77. [CrossRef]

(C) 2019 by the authors. Licensee MDPI, Basel, Switzerland. This article is an open access article distributed under the terms and conditions of the Creative Commons Attribution (CC BY) license (http://creativecommons.org/licenses/by/4.0/). 